\title{
Activity of Class III Peroxidases in the Defense of Cotton to Bacterial Blight
}

\author{
E. Delannoy, ${ }^{1}$ A. Jalloul, ${ }^{1}$ K. Assigbetsé, ${ }^{1}$ P. Marmey, ${ }^{1}$ J. P. Geiger, ${ }^{1}$ J. Lherminier, ${ }^{2}$ J. F. Daniel, ${ }^{1}$ \\ C. Martinez, ${ }^{3}$ and M. Nicole ${ }^{1}$ \\ ${ }^{1}$ IRD, UMR « DGPC », "Résistance des Plantes", BP 64501, 34394 Montpellier, France; ${ }^{2}$ INRA, Service Commun de \\ Microscopie Electronique, BV 1540, Dijon cedex 21034 France; ${ }^{3}$ S.O.F.T. Laboratoire GBSA, Case Courrier 024, \\ Université Montpellier II, Place Eugène Bataillon, 34095 Montpellier Cedex 05, France
}

Submitted 19 March 2003. Accepted 30 June 2003.

\begin{abstract}
Cotton cotyledons displayed a hypersensitive reaction (HR) in the cultivar Réba B50 after infiltration with the avirulent race 18 from Xanthomonas campestris pv. malvacearum. Two sets of peroxidases were associated with the HR time course. Early but transient accumulation of peroxidase in material encapsulating the bacteria in intercellular areas was observed by immunocytochemistry at $3 \mathrm{~h}$ postinfection and coincided with the oxidative burst. Total guaiacol-peroxidase activity was highly increased in cells undergoing $\mathrm{HR}$, from $12 \mathrm{~h}$ after treatment. Molecular characterization of seven cloned peroxidase genes revealed highly conserved $\mathrm{B}, \mathrm{D}$, and $\mathrm{F}$ domains, with similarities to plant class III peroxidases. Analysis of gene expression showed variation in transcript accumulation during both compatible (race 20) and incompatible interactions for four of these genes: pod2, pod3, pod4, and pod6. Pod4 and pod6 were more intensely up-regulated during resistance than during disease and in the control, while pod3 was specifically down-regulated during the $H R$ after the oxidative burst. Pod 2 was induced by pathogen infection and weakly stimulated in the control. These data suggest that cotton peroxidases may have various functions in the defense response to Xanthomonas infections.
\end{abstract}

Additional keywords: Gossypium, apoplasm.

Resistance of cotton (Gossypium hirsutum) to bacterial blight caused by Xanthomonas campestris pv. malvacearum (Hillocks 1992) is mediated by gene for gene interactions (De Feyter et al. 1993; Follin et al. 1988; Gabriel et al. 1986). The resistance phenotype is characterized by rapid localized tissue collapse, resulting in necrotization (hypersensitive response $[\mathrm{HR}])$ and immobilization of the intruding pathogen at the sites of attack (Al Mousawi et al. 1982). At least 22 major resistance genes, so-called B genes, are reported as dominant resistance factors in $G$. hirsutum resistance (Hillocks 1992). The cultivar Réba B50 carries $\mathrm{B}_{2} \mathrm{~B}_{3}$ bacterial blight resistance genes that confer immunity to several $X$. campestris pv. malvacearum races, including race 18 (Innes 1983).

Studies on the nature of cotton resistance to $X$. campestris pv. malvacearum have focused on a wide range of events occurring mainly within the first $24 \mathrm{~h}$ postinfection (pi). The oxi-

Corresponding author: M. Nicole: E-mail: nicole@mpl.ird.fr.

Current address for A. Jalloul: Faculty of Agronomy, University of Damascus, Syria. dative burst ( $3 \mathrm{~h} \mathrm{pi}$ ) is characterized by the production of active oxygen species (AOS), including superoxide anions $\left(\mathrm{O}_{2} \cdot\right)$ and hydrogen peroxide $\left(\mathrm{H}_{2} \mathrm{O}_{2}\right)$ (Martinez et al. 1998). It acts upstream of salicylic acid (SA) accumulation (6 h pi) (Martinez et al. 2000). Histopathological studies indicated that rapid membrane rupture and cell collapse were important features in the cotton HR (Cason et al. 1978; Daï et al. 1996; Hopper et al. 1975). Recently, cotton cell death during the HR was shown to be strongly associated with 9S-lipoxygenase (LOX)-dependent lipid peroxidation and correlated with water loss of infected tissues and appearance of HR lesions (Jalloul et al. 2002). Both jasmonic acid (JA), which accumulated early $2 \mathrm{~h}$ pi, and SA induce cotton LOX1 gene expression and activity (A. Jalloul, unpublished data). Sesquiterpene phytoalexins elicited by the pathogen (Abraham et al. 1999) accumulated in hypersensitive cells adjacent to $X$. campestris pv. malvacearum colonies to concentrations sufficient to account for bacteriostasis (Essenberg et al. 1990). Activity of the sesquiterpene cyclase, the first enzyme in the biosynthetic pathway of sesquiterpenoid defense compounds, was shown to increase at $24 \mathrm{~h}$ pi (Davila-Huerta et al. 1994). Flavonoids were detected in the cytoplasm and walls of cells reacting hypersensitively, but there was no evidence of their antibacterial activity (Daï et al. 1996).

Peroxidases (POD) (EC 1.11.1.1.7), a group of heme-containing glycosylated proteins, are known to be activated in response to pathogen attacks. Several roles have been attributed to plant POD in host-pathogen interactions (Chittoor et al. 1999), including xanthomonad-induced resistance (Brown et al. 1998; Chittoor et al. 1997; Do et al. 2003; Hilaire et al. 2001; Young et al. 1995). The correlation between increased POD activity during incompatible interactions and reinforcement of cell walls with phenol compounds was also reported (Reimers et al. 1992). In cotton cultivars, association of POD activity with resistance to the bacterial blight was suspected (Martinez et al. 1996; Venere 1980). Martinez and associates (1998) showed that apoplastic cationic isoforms of POD generated $\mathrm{O}_{2}-$ during the $\mathrm{HR}$ of cv. Réba B50 to $X$. campestris pv. malvacearum race 18 , and they and others (Bolwell et al. 2002) suggested that POD may be involved in the oxidative burst. In addition, total POD activity was stimulated following SA or $\mathrm{H}_{2} \mathrm{O}_{2}$ treatments, both at cotyledon infection sites, and systemically in the whole plant in relation with acquired resistance (Martinez et al. 2000). Here, we investigated the possibility that the dramatic increase in total POD activity in cotton cotyledons challenged by $X$. campestris pv. malvacearum race 18 (Martinez et al. 1996) may be associated with variation in POD gene expression. Immunocytolocalization in planta of POD proteins was performed during the HR time course, using 
polyclonal antibodies raised against purified cotton POD. In parallel, we isolated seven class III POD genes cloned from cotton cDNA libraries, and changes in their expression were examined with emphasis on differential induction during cotton resistance and susceptibility.

\section{RESULTS}

\section{Changes in peroxidase activity during infection.}

POD activity was assessed spectrophotometrically according to time course of infection (Fig. 1). It increased significantly during the incompatible interaction between 8 and $10 \mathrm{~h} \mathrm{pi}$, as compared with the activity in the compatible interaction (Réba B50-X. campestris pv. malvacearum race 20) and the control. Tissue printing of whole $X$. campestris pv. malvacearum race 18-infected Réba B50 cotyledons onto nitrocellulose membranes followed by revelation of POD activity showed strong at HR sites from 10 to $18 \mathrm{~h}$ pi (Fig. 2A and B). A weaker reaction was noted in noninfected areas of $X$. campestris pv. malvacearum-infiltrated cotyledons. At the same time, $X$. campestris pv. malvacearum race 20 -infected cotyledon tissue prints did not reveal any difference in POD activity as compared with controls (not shown).

\section{Immunocytolocalization of peroxidase.}

Ultrathin sections from $X$. campestris pv. malvacearuminfected resistant cotyledons were incubated on primary antiPOD antibody (1:30) followed by treatment with goat antirabbit conjugated to colloidal gold. This is a polyclonal antibody that likely reacts with several different peroxidases. At $3 \mathrm{~h} \mathrm{pi}$, ultrastructural observations of ultrathin sections from $X$. campestris pv. malvacearum-infected resistant cotyledons revealed dense labeling over the material encapsulating bacteria in the intercellular areas (Fig. 3A; Table 1). Gold particles were also present on the middle lamella (Fig. 3B) and secondary cell walls (Fig. 3C). Weak labeling was detected over the cytoplasm of host cells. At $6 \mathrm{~h}$ pi (Table 1), gold particles weakly decorated the bacteria-encapsulating material. The cytoplasm of mesophyll cells that underwent the HR displayed

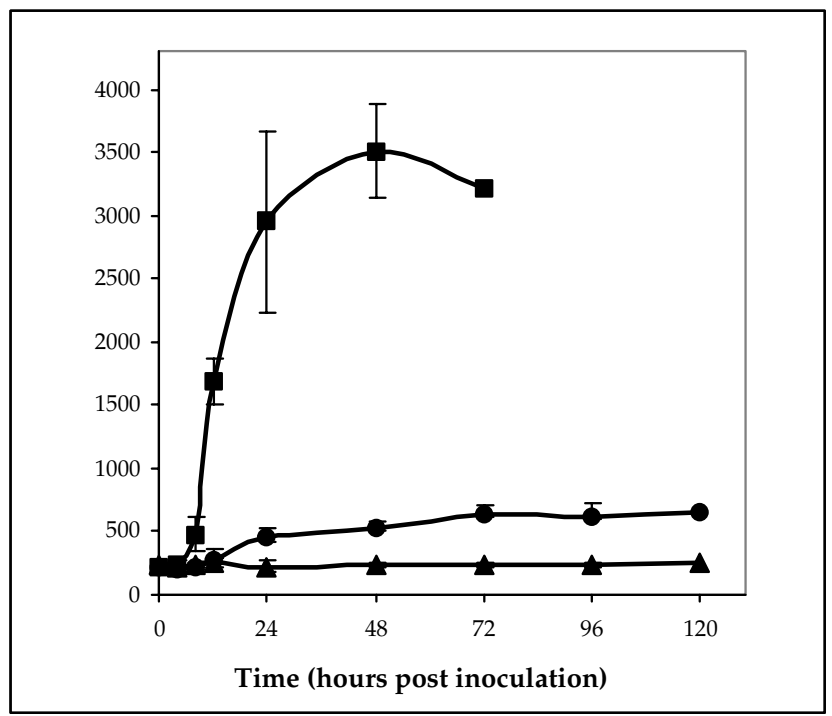

Fig. 1. Time course of total peroxidase (POD) activity during infection. A significant increase in activity is observed from $8 \mathrm{~h}$ postinfection in the incompatible interaction ( $\mathbf{\square}$ ), as compared with the water-infiltrated plant control ( $\mathbf{\Delta})$. A weak but positive increase was also noted in the compatible Réba B50-Xanthomonas campestris pv. malvacearum race 20 interaction (๑). POD activity was spectrophotometrically assessed at $470 \mathrm{~nm}$, using guaiacol as hydrogen donor. irregular labeling. Gold particles were also unevenly distributed over the middle lamella. On immunotreated sections from 18-h infected cotyledons (Table 1), labeling was weak over the bacteria-encapsulating material and of variable density over host cell cytoplasm within the infected areas (Fig. 3D). An analysis of labeling density (gold particles per $\mu \mathrm{m}^{2}$ ) showed high standard errors, indicating variation in gold decoration and suggesting local, not general, POD accumulation.

In water-infiltrated cotyledons, a weak decoration of host cell cytoplasm and walls was detected (Fig. 3E), while middle lamella (Fig. 3F) and secondary cell walls also displayed numerous gold particles. During the compatible interaction, weak or no differences in gold labeling were noted between infected cells and controls at 3,6 , and $18 \mathrm{~h}$ pi (Table 1). Negative results (data not shown) were obtained for controls, which included incubation of sections with i) the antibody to which the corresponding antigenic molecules was previously added (data not shown), ii) preimmune rabbit serum instead of primary antiserum (Table 1), and iii) omission of the primary antibody incubation step.

\section{Isolation of peroxidase genes of cotton.}

To isolate pathogen-inducible peroxidase genes involved in the interaction, we screened two cDNA libraries constructed with RNA isolated 2.5 and $5.5 \mathrm{~h}$ pi. Approximately 1.5 million phages from each library were screened, and 45 clones were
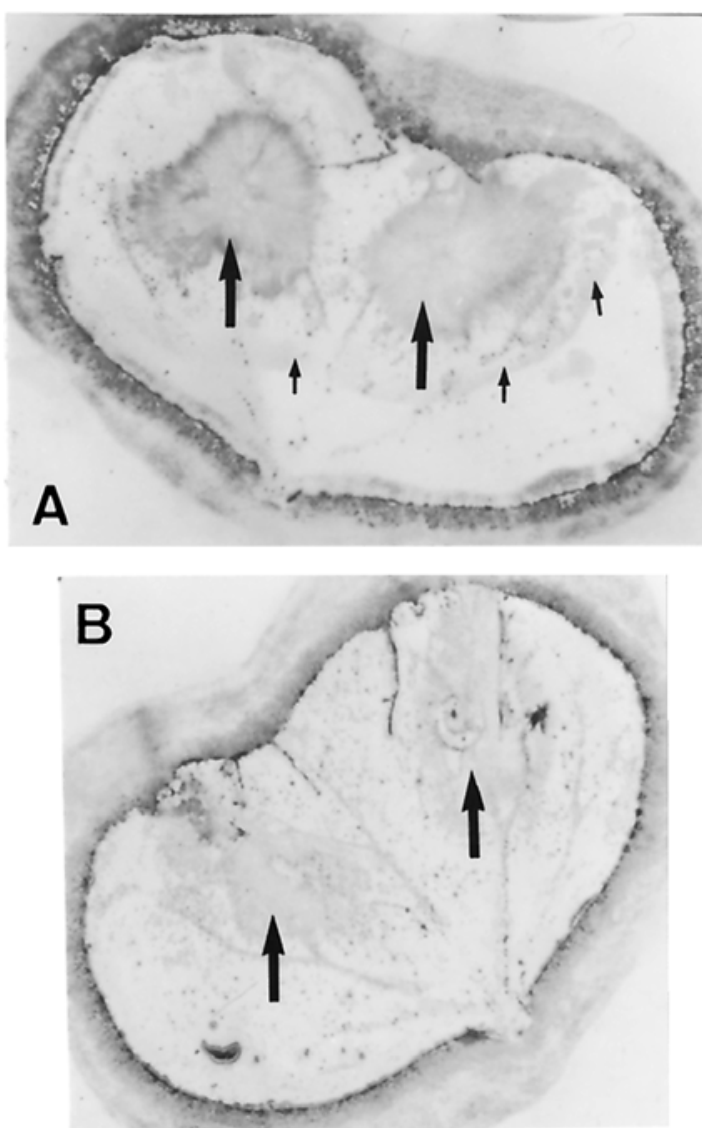

Fig. 2. Detection of peroxidase (POD) activity on cotyledon tissues from the resistant cultivar Réba B50, after blotting onto nitrocellulose membrane $(0.2 \mu \mathrm{m})$ and incubation for $2 \mathrm{~min}$ in the POD substrate $(0.2 \%$ guaiacol, $0.01 \%$ 3-amino-9-ethylcarbazole, $0.03 \% \mathrm{H}_{2} \mathrm{O}_{2}$ in $0.05 \mathrm{M}$ sodium phosphate buffer, $\mathrm{pH}$ 6). A, Cotyledon inoculated with the pathogen, $18 \mathrm{~h}$ postinfection. Strong activity is visible at sites of bacterial infiltration (large arrows), and weak activity is seen in portions of the noninoculated mesophyll (small arrows). B, Cotyledon infiltrated with water. POD activity is weakly detected in the treated areas (arrows). 

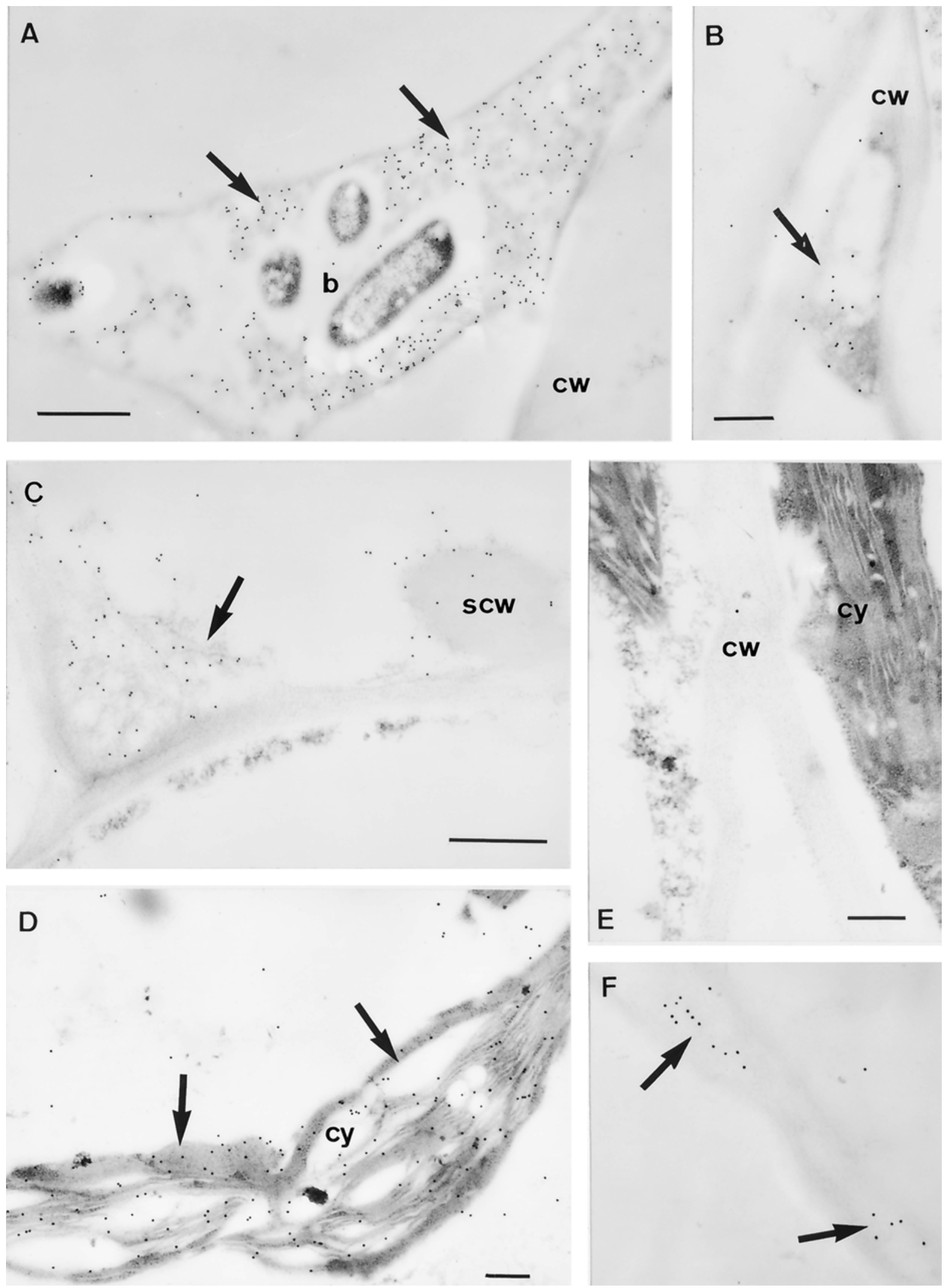

Fig. 3. Immunocytolocalization of cotton peroxidases (POD) using anti-POD polyclonal antiserum (1:30), followed by gold-labeled goat antirabbit antibodies (1:20). A through $\mathbf{C}$, Observations of sections from Réba B50 cotyledons $3 \mathrm{~h}$ postinfection (pi) with Xanthomonas campestris pv. malvacearum race 18. Numerous gold particles are seen over the bacterial encapsulating material (A, arrows). This labeled material is closely associated with the middle lamella (B, arrow). Gold decoration is weak over the intercellular areas, the host cell wall (cw), the bacteria (b), and the cytoplasm. Bars : $\mathrm{A}=1 \mu \mathrm{m} ; \mathrm{B}=0.5 \mu \mathrm{m}$. C, Gold particles are abundant over secondary cell walls (scw, arrow) of xylem vessels. Bar $=1 \mu \mathrm{m}$. D, Observations of sections from Réba B50 cotyledons $18 \mathrm{~h}$ pi with X. campestris pv. malvacearum race 18. Numerous gold particles are seen over the cytoplasm of cells undergoing a hypersensitive reaction (cy, arrows). Bar $=0.3 \mu \mathrm{m}$. $\mathbf{E}$ and $\mathbf{F}$, Observations of sections from Réba B50 cotyledons $18 \mathrm{~h}$ pi with water. E, Over the cytoplasm (cy) and walls (cw) of mesophyll cells, only a few gold particles are seen. Bar $=0.3 \mu \mathrm{m}$. F, Labeling is regular and more intense over portions of the middle lamella (arrows). Bar $=0.3 \mu \mathrm{m}$. 
isolated. Sequence analysis revealed that 20 of them contained peroxidase-related sequences. Among the peroxidase-related clones, 12 were identical to pod4 (Assigbetsé et al. 1999) (GenBank accession number AF155124), and the other clones encoded five distinct peroxidase-related sequences: podl (accession number AF485266), pod2 (accession number AY074794), pod3 (accession number AF485265), pod5 (accession number AF485267), and pod6 (accession number AF485268). Pod10 (accession number AF488305) was subsequently identified by polymerase chain reaction (PCR) from cDNA libraries.

Sequence analysis and comparison revealed that sizes of pod1, pod2, pod3, pod5, pod6, and pod 10 ranged from 1,125 to $1,531 \mathrm{bp}$, representing unreported full-length peroxidase coding sequences. The deduced amino-acid sequences indicated that the size of each potentially encoded protein ranged from 320 (pod3) to 347 (pod10) residues (Fig. 4), with an estimated molecular mass of 32 to $35 \mathrm{kDa}$ (Table 2). As with Arabidopsis thaliana class III POD genes (Tognolli et al. 2002), the seven cotton genes are identified as class III POD by their three highly conserved domains $\mathrm{B}, \mathrm{D}$, and $\mathrm{F}$; these domains are common to plant peroxidases and reported to be important in catalysis and protein folding (Welinder 1992). Apart from these domains, the remaining sequence of the genes is highly variable. Multiple alignment of predicted amino acid sequences of the putative peroxidase cDNA clones, pod4, and horseradish peroxidase C (HRPC1) showed sequence differences (Fig. 4); they displayed less than 55\% identity with each other, except for pod 2 and pod6 (79\%) and pod3 and pod4 (62\%). This high diversity may reflect the large number of roles that class III POD can have in plants. Furthermore, there are no clear homologues of these cotton genes in other plants, except for pod 2 which is $75 \%$ identical to TO7008, a tomato peroxidase induced by ethylene and during virus infections (Gadea et al. 1996). Putative signal peptide cleavage sites were identified in the coding sequence of all the clones (Fig. 4), and no clear peroxisomal targeting signal sequences were detected, thus suggesting that these POD are located extracellularly (Table 2).

\section{Expression of peroxidase \\ during cotton- $X$. campestris pv. malvacearum interactions.}

The expression profile of each cDNA clone was determined by reverse transcriptase (RT)-PCR, using specific primers (Table 3) at different pi times. The mRNAs of podl, pod5, and pod10 were detected in healthy cotyledons and after water infiltration, showing expression from 0 to $48 \mathrm{~h}$ pi. These genes did not show significant modulation of their expression during either of the interactions.

Pod3 was also constitutively expressed in cotyledons. Its expression remained stable in the control but decreased during the HR; the signal was no longer detectable by $12 \mathrm{~h}$ pi. It also slightly decreased during the compatible interaction.

In contrast to these genes, expression of pod4 and pod6 was only weakly or not detected in cotyledons. However, they were rapidly and highly induced during both compatible and incompatible interactions and by water infiltration. Accumulation of mRNA, which was observed as early as $2 \mathrm{~h}$ pi and was still detected 36 to $48 \mathrm{~h}$ pi, was at much higher levels in infected resistant plants, as compared with the compatible interaction and the control.

Pod2 expression, which was weakly detected in the control, was induced by both $X$. campestris pv. malvacearum race 20 and race 18. Messenger RNA accumulated from $2 \mathrm{~h}$ pi to 36 to $48 \mathrm{~h}$ pi in the susceptible interaction, while a distinct pattern of expression with two phases was revealed during HR from 2 to $6 \mathrm{~h}$ pi and at $18 \mathrm{~h}$ pi.

\section{DISCUSSION}

The oxidative burst in plants infected by incompatible pathogens is a key early event in the expression of resistance (Wojtasjeck 1997). It was suggested that POD of cotton participate in the defense reaction to $X$. campestris pv. malvacearum, including AOS generation in the HR of cotyledons (Martinez et al. 1996; Venere 1980), prompting us to further investigate cotton POD expression at cytological and molecular levels. In the present work, we demonstrated that POD activity and distribution were modified within cotyledon cells undergoing the HR. Seven peroxidase genes were cloned with similarities to plant class III POD, also referred to as classical guaiacol POD. These proteins found in the vacuole or apoplasm have been implicated in a broad range of physiological processes (Hiraga et al. 2001). Variations in immunogold labeling on sections from cotton cotyledons suggest two levels of response, one occurring primarily $3 \mathrm{~h}$ pi, close to the encapsulated pathogen confined in the apoplasm, and the second, in the cytoplasm, associated with changes in total POD activity starting around $10 \mathrm{~h}$ pi. Using tissue printing methods, no apparent substantial modification was detected in areas surrounding HR sites before $20 \mathrm{~h}$ pi. However, a subsequent systemic increase in POD activity was recorded one day after bacterial treatment, both locally in noninfected areas of cotyledons and in the whole plant (Martinez et al. 2000). A weaker increase in activity was also observed in the compatible interaction.

The highly localized accumulation of POD proteins in cotton cells $3 \mathrm{~h}$ after $X$. campestris pv. malvacearum infiltration, which was revealed by immunolabeling with semiquantitation of gold particle distribution, is consistent with diamino-benzidine cytochemistry observations showing that POD activity was con-

Table 1. Density of labeling ${ }^{\mathrm{a}}$

\begin{tabular}{|c|c|c|c|}
\hline \multirow[b]{2}{*}{ Cell compartment } & \multicolumn{3}{|c|}{ Time after infection (hours) } \\
\hline & 3 & 6 & 18 \\
\hline \multicolumn{4}{|c|}{ Inoculated with the $X$. campestris pv. malvacearum race $18^{b}$} \\
\hline Plant cell wall & $30 \pm 26$ & $5 \pm 7$ & $4 \pm 6$ \\
\hline Middle lamella & $83 \pm 30$ & $57 \pm 44$ & $15 \pm 12$ \\
\hline Plant cytoplasm & $9 \pm 7$ & $43 \pm 22$ & $32 \pm 8$ \\
\hline Bacteria & $6 \pm 4$ & $3 \pm 3$ & $5 \pm 4$ \\
\hline Encapsulating material & $95 \pm 45$ & $16 \pm 14$ & $2 \pm 1$ \\
\hline Background & $2 \pm 2$ & $2 \pm 3$ & $2 \pm 1$ \\
\hline \multicolumn{4}{|l|}{ Infiltrated with water ${ }^{b}$} \\
\hline Plant cell wall & $3 \pm 5$ & $5 \pm 5$ & $4 \pm 5$ \\
\hline Middle lamella & $17 \pm 17$ & $12 \pm 7$ & $15 \pm 5$ \\
\hline Plant cytoplasm & $8 \pm 5$ & $15 \pm 5$ & $16 \pm 5$ \\
\hline Bacteria & $\ldots$ & $\ldots$ & $\ldots$ \\
\hline Encapsulating material & $\ldots$ & $\ldots$ & $\ldots$ \\
\hline Background & $2 \pm 1$ & $3 \pm 2$ & $2 \pm 1$ \\
\hline \multicolumn{4}{|c|}{ Inoculated with the $X$. campestris pv. malvacearum race $20^{\mathrm{b}}$} \\
\hline Plant cell wall & $2 \pm 3$ & $4 \pm 2$ & $5 \pm 3$ \\
\hline Middle lamella & $12 \pm 6$ & $9 \pm 6$ & $8 \pm 4$ \\
\hline Plant cytoplasm & $10 \pm 5$ & $9 \pm 4$ & $21 \pm 7$ \\
\hline Bacteria & $\ldots$ & $\ldots$ & $\ldots$ \\
\hline Encapsulating material & $\ldots$ & $\ldots$ & $\ldots$ \\
\hline Background & $1 \pm 1$ & $2 \pm 2$ & $1 \pm 1$ \\
\hline \multicolumn{4}{|c|}{ Inoculated with the $X$. campestris pv. malvacearum race $18^{c}$} \\
\hline Plant cell wall & $1 \pm 1$ & $0 \pm 0$ & $0 \pm 0$ \\
\hline Middle lamella & $0 \pm 0$ & $0 \pm 0$ & $1 \pm 1$ \\
\hline Plant cytoplasm & $0 \pm 0$ & $0 \pm 0$ & $0 \pm 0$ \\
\hline Bacteria & $0 \pm 0$ & $0 \pm 0$ & $0 \pm 0$ \\
\hline Encapsulating material & $1 \pm 1$ & $0 \pm 0$ & $0 \pm 0$ \\
\hline Background & $1 \pm 1$ & $0 \pm 0$ & $0 \pm 0$ \\
\hline
\end{tabular}

Vol. 16, No. 11, $2003 / 1033$ 
fined in the apoplasm and close to the bacteria (Martinez et al. 1998). POD identified in the apoplastic washing fluid were shown to be i) cationic, ii) responsible for the production of superoxide anions subsequently dismutated into wall-bound $\mathrm{H}_{2} \mathrm{O}_{2}$, iii) preformed, since they were detected in healthy cotyledons, and iv) inducible for their superoxide anion-generating NADH-oxidase activity in noninfected tissues (Martinez et al. 1998). Similarly, in other pathosystems, apoplastic POD were associated with $\mathrm{H}_{2} \mathrm{O}_{2}$ production (Blee et al. 2001; Brown et al.
1998) and oxidative cross-linking activity (Bestwick et al. 1998) with ability to reduce a wide range of substrates. POD accumulation in X. campestris pv. malvacearum-encapsulating material is a response to HR development and suggests that cotton cells challenged by the pathogen create a localized, highly toxic environment, in line with AOS production, which results in limiting bacterial growth (Nicholson and Hammerschmidt 1992). This confined apoplastic localization of active POD may explain why the change in activity $3 \mathrm{~h}$ pi was not observed spectropho-

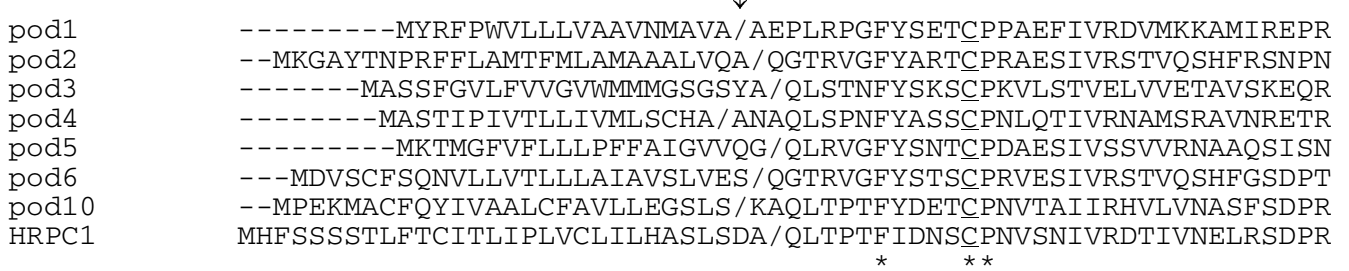

$\operatorname{pod1}$

pod3

pod4

pod5

pod6

pod10

HRPC1

pod1

pod2

pod4

pod5

pod6

pod10

HRPC 1

pod1

pod3

pod4

pod5

pod6

pod10

HRPC 1

pod1

pod2

pod3

pod4

pod5

pod6

pod10

HRPC1

pod1

pod2

pod3

pod4

pod5

pod6

pod10

HRPC1

\section{B}

SLASVMRLQFHDCFFVGCCDGSLLLDDTADMVGEKQALSNINSLRSFEVVDEIKEALEDACCPS IAPGLLRMHFHDC FVQGCDASILID-GPNTEKTAPPNRLLR---GYEVIDDAKTQLEATC्CPG LGASLLRLFFHDCFVNGCDGSVLLDDTSSFTGEQTATPNNGSLRGFEVVDEIKAKVEKVCPG IGASILRLFFHDC $F$ FNG $\underline{C}$ DGSILLDDTATFTGEKNAVPNRNSARGFEVIDTIKTNVEAAC SA IPPVLLRLHFHDCFVEGCDGSILIENGPKAERHAFGHQGVG---GFEVIEQAKAQLEATCPG IAPGLLRMHFHDCFVHGCDASILID-GPGTEKTAPPNLLLR---GYEVIDDAKTQLEAACPG IGASLIRLHFHD $\bar{C} F V Q G \underline{C} D A S I L L D D P V N G--E K E A$ I PNNNSARGYEVIDAMKAALESA $\underline{C} P N$ IAAS ILRLHFHD $\underline{\bar{C}}$ FVNG $\underline{D} D A S I L L D N T T S F R T E K D A F G N A N S A R G F P V I D R M K A A V E S A \underline{C} P R$

$\star \quad \star \star \star \star * * * \star \star * * * *$

D

TVSCADILVLAARDAVA-LSGGPNWEVRLGRKDSLTASQQDSDN-IMPSPRADATSLINLFA VVSCAADILTLAARDSVF-LTRGINWAVPTGRRDGRASLASDTTI--LPGFRESIDSQKQKFA VVSCADILAIAARDSVV-ILGGPDWDVKLGRRDSKTASF SDANSGVLPLGSANLSOLISLFA TVSCAADILALAARDGVA-LLGGPTWQVPLGRRDARTASQSAANN-QIPSPFANLATLTSSFA VVSCEADIVALAARDAIA-LANGPSYEVPTGRRDGRVSDVSLAAN--MPDVSDSIQQLKAKFL VVSCADILALAARDSVV-LSSGASWAVPTGRRDGTVSQASDAAN--LPGFRDSVDVQKQKFA TVSCEADILAIASEQSVSTLAGGPSWAVPLGRRDGFTANRTLANS-NLPGFNNTLDRLKNRFS TVSCADLLTIAAQQSVT-LAGGPSWRVPLGRRDSLQAFLDLANA-NLPAPFFTLPQLKDSFR

$\mathbf{F}$

OFNLS-VKDLVALSGSHSIGKARCFS IMFRLYNOSGSG-KPDPAIEPEFREKLNOLCPLG- AFGLN-TQDLVALVGGHTIGTSA $\underline{C} Q L F S Y R L Y N F T N G-$-GPDPTVNSAFVPQLQALC $P Q N-$ AQGLS-TKDMVALSGAHTIGKARCLLVFRNRIYN-------DTIIDTSFAKTRRSS $\underline{\text { PPRTRG }}$ AKGLS-TRDLTALSGGHTIGLARCTTFRGRIYN-------DTNIDANFAATRRANCPAS-QKGLS-EKDLVLLSAAHTIGTTA AKGLN-TQDLVTLVGGHTIGTTACOFFRYRLYNFTTTGNGADPSITAAFVSQLQALC PQN-NVGLNTSIDLVALSGAHTFGRAQCLTFTSRLYNFTGVG-DTDPTLNATYLEELRQICPQG--

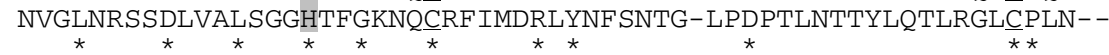

-VDENVTGPLDATPRVFDNQFFKDLVGGRGFLNSDQTLFT---SRRTRPYVRVFSKDQD--GDGSRLIDLDTGSGNRFDTSFFANLRNVRGILESDQKLWT---DPSTRTFVQRFLGERG-SR SGDNNLAPLDLATPNSFDSKYFENLLNKKGLLHSDQELFN---GGSTDSLVKTYSSNVK--GGDNNLAPLDIQTPTRFDNDYFRNLVARRGLLHSDQELFN---GGSQDALVRTYSNNPA--GDVNVRLPMDRGSERTFDKQILDNIRNGFAVLESDARLYD---DETTRMVVDSYFGILTPIF GDGSRRIGLDTGSVNRFDNSFFANLRDGKGILESDQRLWT---DASTKTFVQRFLGIRG-LL GNSSVLTNLDPTTPDGFDNNYFTNLQVNRGLLRSDQNLFS-TEGADTIEIVNRFSSNQT--GNLSALVDFDLRTPTIFDNKYYVNLEEQKGLIQSDQELFSSPNATDTIPLVRSFANSTQ---

$$
\text { ** ** * }
$$

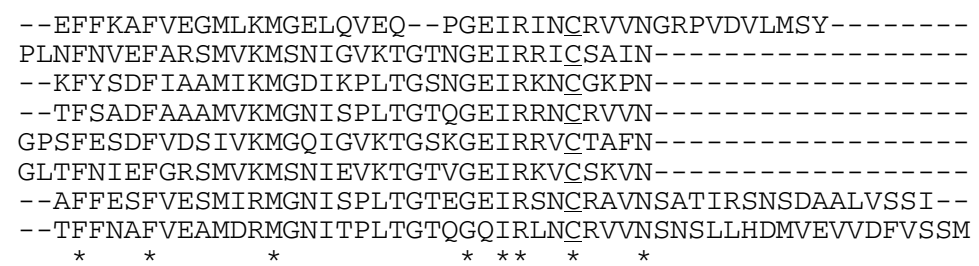

Fig. 4. Multiple alignment of deduced amino acid sequences of putative peroxidase cDNA clones of Gossypium hirsutum compared with horseradish peroxidase $\mathrm{C}$ and pod4, using ClustalW 1.81 (Infobiogen, Paris). Asterisks $(*)$ identify identical amino acids, dashes represent gaps introduced to maximize similarity. The downward arrow $(\downarrow)$ indicates a potential signal peptide cleavage site. The conserved cysteines (involved in the formation of disulfide bridges) are underlined, and histidines (involved in heme binding) are dashed. Horizontal lines represent the conserved catalytic and distal heme binding domain (B), proximal heme binding domain (F), and central conserved domains of unknown function (D) (Welinder 1992). 
tometrically but only on isoelectric focusing (IEF) gels with reference to apoplastic cationic isoforms (Martinez et al. 1998).

Although pod 2 , pod4, and pod6 genes encode cationic proteins based on their putative pI, our data showed that their transcriptional activity was not correlated with the immunological and biochemical observations. In contrast, the expression of pod3, which also putatively encodes an apoplastic cationic protein, was constitutive but restricted to photosynthetic tissues (data not shown) and was inhibited by 10 to $12 \mathrm{~h}$ pi during the cotton HR. This pod3 profile was associated with peaks in accumulation of immunolabeled POD and IEF activity and coincided with the oxidative burst. Investigations are currently under way to determine whether pod11 might correspond to apoplastic POD with superoxide anion-generating NADHoxidase activity (Martinez et al. 1998) and whether it might be cationic POD associated with plant defense to xanthomonads. In Capsicum annuum infected with $X$. campestris pv. vesicatoria (Do et al. 2003), the drastic increase in $\mathrm{H}_{2} \mathrm{O}_{2}$ production was correlated with extinction of ascorbate and thioredoxin PODlike gene expression.

Immunocytological observations in cotton showed localization of POD within the middle lamella bordering intercellular areas and the matrix surrounding the pathogen, suggesting close physical interactions between POD and pectin. Recent cell biological analysis revealed the presence of pectinlike molecules in material encapsulating the bacteria (E. Delannoy and M. Nicole, unpublished data). Binding of plant POD with oligogalacturonides in the presence of calcium was reported, thus suggesting that pectin may influence the distribution of POD within the apoplasm (Carpin et al. 2001; Penel and Greppin 1996; Penel et al. 1999, 2000). The possibility that calcium may have a crucial dual role during HR of the cotton genotype Réba B50 to $X$. campestris pv. malvacearum should be investigated in light of regulation of the oxidative burst by optimizing apoplastic POD activity (Bolwell 1999) and formation of pectic gels that trap the pathogen.

The increase in total POD activity from 12 to $18 \mathrm{~h}$ pi (Fig. 1), dramatic during resistance and slight during disease, was associated with cytoplasmic localization of POD and an increase in transcriptional activity of pod4 and pod 29 genes, mainly during HR. The detection of these gene activities in water-infiltrated tissues suggests that these POD are stress-related rather than resistance-related proteins. Conversely, pod1, pod5, and pod10 encoding putatively anionic isoforms did not display significant transcriptional activity related to either of these interactions. Preferential stimulation of transcriptional activity of the putative cationic protein-encoding pod 2 gene in both interactions but not in the control (Fig. 5) indicates that this gene may play a role in the cotton response to $X$. campestris pv. malvacearum infection. The expression profile and high sequence identity of $\operatorname{pod} 2$ with a virus- and ethylene-induced POD gene (Gadea et al. 1996) suggests that pod2 might encode a pathogen-induced defense protein that is differentially regulated during resistance versus disease.

The physiological function that proteins encoded by pod 2 , pod4, and pod6 genes may have in local expression of cotton defense to $X$. campestris pv. malvacearum still remains ob-

Table 2. Relevant features of peroxidase sequences from cotton

\begin{tabular}{|c|c|c|c|c|c|c|c|}
\hline \multirow[b]{2}{*}{ Sequence features } & \multicolumn{7}{|c|}{ Peroxidase clones } \\
\hline & pod1 & $\operatorname{pod} 2$ & pod3 & pod4 & pod5 & pod6 & pod10 \\
\hline Length (bp) & 1,125 & 1,330 & 1,335 & 1,369 & 1,531 & 1,389 & 1,250 \\
\hline Amino acid sequence length of the putative protein & 329 & 328 & 320 & 317 & 323 & 328 & 347 \\
\hline Potential signal peptide cleavage sites ${ }^{\mathrm{a}}$ & 19 to 20 & 27 to 28 & 23 to 24 & 19 to 20 & 21 to 22 & 26 to 27 & 26 to 27 \\
\hline Estimated molecular mass of mature protein $(\mathrm{kDa})^{\mathrm{b}}$ & 34.3 & 32.8 & 34.4 & 31.7 & 32.5 & 32.4 & 34.6 \\
\hline Estimated pI for mature protein ${ }^{\mathrm{b}}$ & 5.29 & 8.87 & 8.46 & 8.72 & 5.66 & 8.34 & 5.15 \\
\hline Potential N'glycosylation sites ${ }^{\mathrm{c}}$ & 3 & 1 & 3 & 2 & 0 & 1 & 10 \\
\hline Probable cellular location ${ }^{\mathrm{d}}$ & $\mathrm{E}$ & $\mathrm{E}$ & $\mathrm{E}$ & $\mathrm{E}$ & $\mathrm{E}$ & $\mathrm{E}$ & $\mathrm{E}$ \\
\hline
\end{tabular}

${ }^{a}$ Sequence analysis performed with SignalP (Center for Biological Sequence Analysis, Lyngby, Denmark).

${ }^{\mathrm{b}}$ Sequence analysis performed with Mwcalc (Infobiogen, Paris).

${ }^{\mathrm{c}}$ Sequence analysis performed with Proscan (Pole Bio-Informatique Lyonnais, Lyon, France).

${ }^{\mathrm{d}}$ Sequence analysis performed with PSORT (GenomeNet, Kyoto, Japan); E = extracellular.

Table 3. List of primers used for polymerase chain reaction (PCR)

\begin{tabular}{|c|c|c|c|}
\hline Primer name & Primer sequence $\left(5^{\prime}\right.$ to $\left.3^{\prime}\right)$ & Amplified gene & PCR product expected size (bp) \\
\hline P18a & TTCCATGACTGCTTTGTTAATGGTTGTGATGG & & \\
\hline Pk1 & CAG CTT CTG CTT TCG TTC TC & pod4 & 1,002 \\
\hline $\mathrm{Pk} 2$ & ACC GAT AAT TGG ATA TGG GC & & \\
\hline Pod1for & GCC CGT CAA CTG TTT CTT GT & podl & 254 \\
\hline pod1rev & GCT TTG CCT ATG GAG TGT GA & & \\
\hline pod2for & CAG TTC AGT CCC ATT TCC GTT C & $\operatorname{pod} 2$ & 727 \\
\hline pod2rev & GAG CCT CTC TCA CCC AAG AA & & \\
\hline pod3for & AAG GCC AAG GTG GAG AAA GT & pod3 & 503 \\
\hline pod3rev & GAT CCG CCA TTG AAG AGT TC & & \\
\hline pod5for & GGC CAA CTA AGA GTG GGG TTC & $\operatorname{pod} 5$ & 725 \\
\hline pod5rev & CCA ACA CTG CAA ACC CAT TCC T & & \\
\hline pod6for & CGC TGC TCG TGA TTC TGT AG & pod6 & 362 \\
\hline pod6rev & CCT GTG TCC AAT CCA ATC CT & & \\
\hline $5^{\prime} \operatorname{pod} 10$ & CGA AGC AAG CCT CGA TTA AC & $5^{\prime}$ pod10 & \\
\hline $3^{\prime} \operatorname{pod} 10$ & CAC AAC ACC TGA TGG TTT CG & $3^{\prime}$ pod10 & \\
\hline pod10for & ACC CCG ACA TTT TAC GAT GA & pod10 & 725 \\
\hline pod10rev & CGA AGC AAG CCT CGA TTA AC & & \\
\hline АCT3 & TAY CCN ATH gAR CAYgg & actin & 300 \\
\hline ACT4 & RTA DAT Ngg NAC NgT RTg & & \\
\hline RACT & GTA GAT GGG GAC GGT GTG AG & actin & 275 \\
\hline LACT & ATT GTG AGC AAC TGG GAT GA & & \\
\hline
\end{tabular}


scure. In rice infected by $X$. oryzae, the activity of the peroxidase gene PO-C1 was shown to be correlated with thickening of vessel secondary cell walls and probably associated with an increase in lignification (Hilaire et al. 2001; Young et al. 1995). However, the lignification response that is sometimes observed in plant HR cells was not detected in cotton cells challenged by the avirulent $X$. campestris pv. malvacearum race 18 (Daï et al. 1996). Recently, an extensive study on the expression of $A$. thaliana class III POD (Welinder et al. 2002) suggested that even similar POD (>70\% identity) do not fulfill similar biological roles. Hence, it is hard to predict the role of a particular POD on the basis of its similarity to another known POD. One response of cotton to $X$. campestris pv. malvacearum was found to be a drastic accumulation of flavonoids in walls and cytoplasm of cells undergoing hypersensitive collapse (Daï et al. 1996), suggesting a possible relation between increased POD activity and phenol oxidation. Since POD were shown to be responsible for peroxidatic degradation of flavonones (Patzlaff and Barz 1978) and to catalyze $\mathrm{H}_{2} \mathrm{O}_{2}$-dependent oxidation of flavonols (Yamasaki et al. 1997), it has been suggested that the flavonoid-POD reaction can function as an $\mathrm{H}_{2} \mathrm{O}_{2}$-scavenging machanism. Consistent with observations that $\mathrm{H}_{2} \mathrm{O}_{2}$ is synthesized apoplastically and flavonoids produced abundantly in cells at the edge of lesions during cotton HR to X. campestris pv. malvacearum, the role of POD as an oxidative damage protectant must be examined in light of the fact that flavonoids are elec-

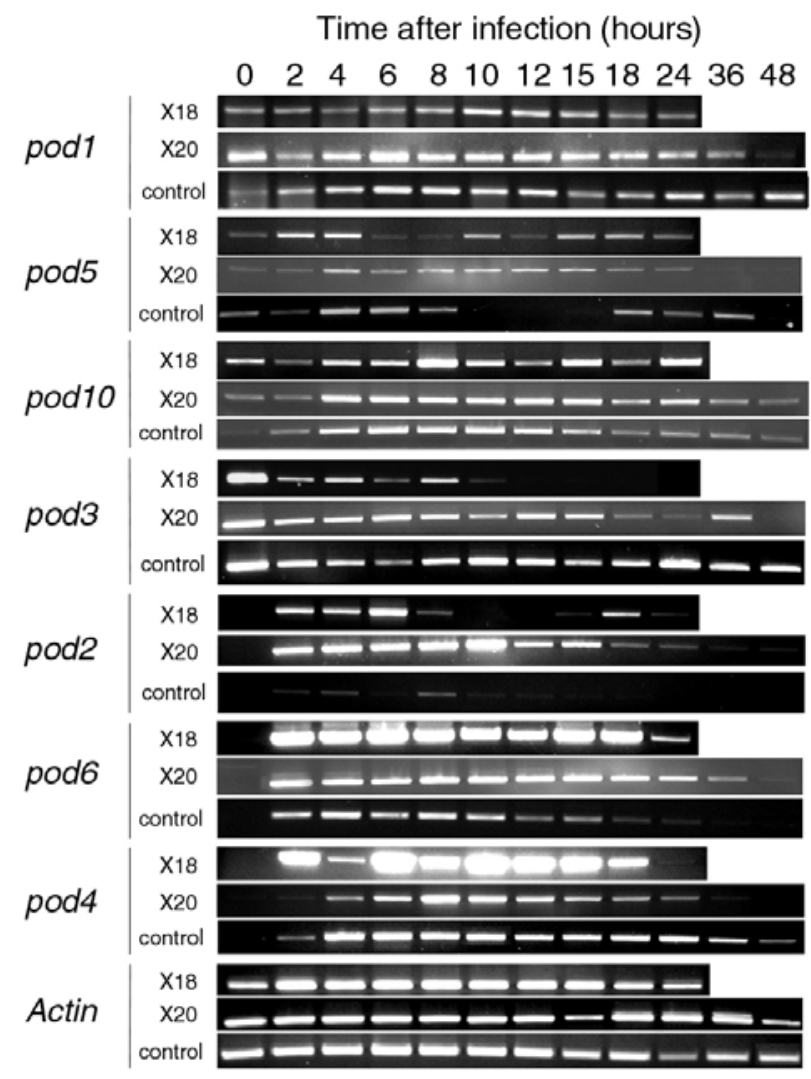

Fig. 5. Changes in peroxidase gene expression within inoculated cotton cotyledons. Total RNA was extracted from water-treated (control), Xanthomonas campestris pv. malvacearum race 18 (avirulent)- or $X$. campestris pv. malvacearum race 20 (virulent)-infected cotyledons at different times after infiltration. Using specific primer pairs, the expression profile of each cDNA clone was determined by reverse transcriptase-polymerase chain reaction (PCR). PCR products were run on $1.5 \%$ agarose gels in Tris-acetate-EDTA buffer, and the band intensities within each experiment were compared after ethidium bromide staining. tron donors. Accordingly, increase in anionic isoform activity was observed in noninfected areas of the inoculated cotyledons between 18 and $20 \mathrm{~h}$ pi (Martinez et al. 2000). Investigations are currently in process to elucidate the function of pod2, pod3, pod4, and pod6 genes using transformed Arabidopsis mutants and to understand the underlying mechanisms involved in regulation of POD genes by the signaling hormones produced in cotton HR to X. campestris pv. malvacearum.

\section{MATERIALS AND METHODS}

\section{Bacterial strains.}

Races 18 and 20 of $X$. campestris pv. malvacearum were maintained at $30^{\circ} \mathrm{C}$ on YPG agar medium $(0.5 \% \mathrm{wt} / \mathrm{vol}$ yeast extract, $0.5 \% \mathrm{wt} / \mathrm{vol}$ bacteriological peptone, and $0.5 \% \mathrm{wt} / \mathrm{vol}$ glucose as a carbon source, solidified with $1.5 \% \mathrm{wt} / \mathrm{vol}$ agar [Difco, Detroit]) in distilled water ( $\mathrm{pH} 7.2$ ). Bacteria for inoculation were grown in $150 \mathrm{ml}$ of YPG medium in a shaking incubator at $150 \mathrm{rpm} / \mathrm{min}$ at $30^{\circ} \mathrm{C}$. After approximately $18 \mathrm{~h}$ of growth, cultures were washed once with water by centrifugation at $10,000 \times g$ for $10 \mathrm{~min}$, to remove nutrients and exopolysaccharides. The bacterial pellet was then resuspended in water and was adjusted to an $A_{600}=10^{7} \mathrm{CFU} / \mathrm{ml}$.

\section{Plant material.}

The cotton cultivar ( $G$. hirsutum) Réba-B50 (Allen $\times$ Stoneville $2 \mathrm{~B}$ ) was used in this study. This cultivar, similar to the 101-102B line, contains $\mathrm{B}_{2} \mathrm{~B}_{3}$ blight resistance genes, which confer immunity to all $X$. campestris pv. malvacearum races, including race 18, except race 20 (Hillocks 1992; Innes 1983). Ten-days-old cotyledons were inoculated by infiltration of the bacterial suspension (Daï et al. 1996). Two interactions were investigated: the incompatible Réba-B50/X. campestris pv. malvacearum race 18 , and the compatible Réba-B50/X. campestris pv. malvacearum race 20 . In control plants, cotyledons were infiltrated with sterile water. These interactions were carried out in a growth chamber under a $30 / 24^{\circ} \mathrm{C}$ and $80 / 90 \%$ relative humidity light/dark cycle with $12 \mathrm{~h}$ of light.

\section{Peroxidase assay.}

POD were extracted in sodium acetate buffer $(0.05 \mathrm{M}, \mathrm{pH} 5$, plus $25 \mathrm{mM} \beta$-mercapto-ethanol). POD activity of crude extracts was spectrophotometrically assessed at $470 \mathrm{~nm}$, using guaiacol as hydrogen donor without 3-amino-9-ethylcarbazole. The molar extinction coefficient is $26.6 \times 10^{3} \mathrm{M}^{-1} \mathrm{~cm}^{-1}$. Total activity is expressed in nKat per mg of proteins. Protein determination is performed by the method of Bradford (1976) with serum albumin bovine as a standard. POD activity on gels was revealed using $0.2 \%$ guaiacol, $0.01 \%$ 3-amino-9-ethylcarbazole, and $0.03 \% \mathrm{H}_{2} \mathrm{O}_{2}$ in $0.05 \mathrm{M}$ sodium phosphate buffer, $\mathrm{pH} 6$.

\section{Tissue printing.}

Tissue printing was performed on whole X. campestris pv. malvacearum-infected or water-infiltrated fresh cotyledons collected 3, 6, 10, and $18 \mathrm{~h}$ pi. Cotyledons were immersed for $30 \mathrm{~s}$ in $70 \%$ ethanol and were gently dried on filter paper before being carefully blotted onto nitrocellulose membrane $(0.2$ $\mu \mathrm{m})$. Both cotyledons and membrane were placed between combined layers of No. 1 Whatman filter paper and aluminum foil. A $20 \mathrm{~kg} / \mathrm{cm}^{2}$ pressure (hydraulic press) was applied for 1 min. The nitrocellulose membrane was then incubated for 2 min in the POD substrate $(0.2 \%$ guaiacol, $0.01 \%$ 3-amino- 9 ethylcarbazole, and $0.03 \% \mathrm{H}_{2} \mathrm{O}_{2}$ in $0.05 \mathrm{M}$ sodium phosphate buffer, $\mathrm{pH}$ 6), was rinsed with distilled water, and then, was air-dried. Areas that stained red exhibited POD activity. Controls were carried out in the absence of $\mathrm{H}_{2} \mathrm{O}_{2}$. 
Preparation of antiperoxidase polyclonal antibodies.

New Zealand white rabbits were immunized by injection of cotton-purified nondeglycosylated anionic POD isoforms (100 $\mathrm{mg} / \mathrm{ml}$ ), three times at 2-week intervals and one time 70 days following the first inoculation. Freund's incomplete adjuvent $(200 \mu \mathrm{l})$ was added for the first injection, and $250 \mu \mathrm{l}$ of Freund's incomplete adjuvent was added for the other injections. The rabbit serum titer was determined by enzyme-linked immunosorbent assay after each injection. The final serum was diluted (1:2) in $1 \mathrm{M}$ phosphate buffer saline (PBS) (pH 7.4) at $4^{\circ} \mathrm{C}$ and was partially purified with $40 \%$ ammonium sulfate. After centrifugation, the pellet was resuspended in PBS and dialyzed using Amicon P10 membrane (Amicon, Beverly, MA, U.S.A.). Preimmune serum was also collected and treated similarly.

\section{Immunocytolocalization of peroxidase.}

Fragments of inoculated or healthy leaf tissues (about 2.0 $\mathrm{mm}^{2}$ ) were fixed for $4 \mathrm{~h}$ in $1 \%$ glutaraldehyde, $4 \%$ paraformaldehyde in $0.1 \mathrm{M}$ cacodylate buffer, $\mathrm{pH} 7.2$, at $4^{\circ} \mathrm{C}$. After dehydration in graded series of ethanol at $4^{\circ} \mathrm{C}$ until $70 \%$ ethanol and $-20^{\circ} \mathrm{C}$ until $100 \%$ ethanol, samples were embedded in LRWhite Medium Grade (TAAB, Aldormaston, England) in a Reichert AFS (Automatic Freeze substitution System), according to a progressive low-temperature protocol at $-19^{\circ} \mathrm{C}$. Resin supplemented with $0.5 \%$ benzoin methyl ether (Sigma, St. Louis) was polymerized for $48 \mathrm{~h}$ at $-19^{\circ} \mathrm{C}$, and then for $3 \mathrm{~h}$ at $10^{\circ} \mathrm{C}$ under UV light. Samples were thin $(90 \mathrm{~nm})$ sectioned with a diamond knife on a Reichert Ultracut E microtome (Leica, Paris) and were examined under a transmission electron microscope operating at $80 \mathrm{kv}$ (Jeol 100EX), after treatment. Sections cut from 3-, 6-, and 18-h-pi cotyledons were monitored. The peak of superoxide anion generation and the end of the oxidative burst in the incompatible interaction corresponded to 3 and $6 \mathrm{~h}$ pi, respectively. The increasing phase of POD activity, as seen in Figure 1, coincided with $18 \mathrm{~h}$ pi. From 2 days pi onward, fixation and embedding of infected tissues were difficult, due to dryness of HR lesions.

For immunolocalization, all solutions were prepared in $20 \mathrm{mM}$ PBS ( $\mathrm{pH} 7.2$ ) with $0.5 \%$ bovine serum albumin (BSA) and $0.05 \%$ Tween 20 (TBST). After blocking in $2.5 \%$ BSA (20 min at room temperature), sections were incubated on a drop of anticotton peroxidase polyclonal antibody diluted in TBST (1:30) for $60 \mathrm{~min}$ at $37^{\circ} \mathrm{C}$. After three washes in TBST ( $10 \mathrm{~min}$ each under gentle shaking), sections were incubated for $30 \mathrm{~min}$ at $37^{\circ} \mathrm{C}$ on gold-labeled goat antirabbit antibodies (GAR-15, Biocell Research Laboratories, Cardiff, U.K.) diluted 1:20 in TBST.

Specificity of labeling was assessed through the following control experiments performed on sections from healthy and infected cotyledons: i) incubation with antibody previously adsorbed with the corresponding antigen, and ii) incubation with preimmune rabbit serum instead of the primary antiserum. Quantitation of labeling (D) over sections was compared by determining the number of gold particles per square $\mu \mathrm{m} \pm$ standard error. The density of labeling was calculated as follows: D $=$ number of gold particles (Ns) divided by surface area (Sa). Densities were determined by counting the number of gold particles over specified cell areas on 8 to 15 micrographs taken randomly from serial sections made on each of three blocks from $X$. campestris pv. malvacearum-infected or water-infiltrated cotyledons.

\section{Construction and screening of two cDNA libraries.}

Two $X$. campestris pv. malvacearum 18-induced cDNA libraries were constructed on the basis of the observed dualphase POD activity during the incompatible interaction. Total RNA was isolated 2.5 and $5.5 \mathrm{~h} \mathrm{pi}$, using the RNeasy plant mini kit (Qiagen, Courtaboeuf, France). Both libraries were constructed using the SMART PCR cDNA library construction kit (Clontech, Palo Alto, CA, U.S.A.) and packaged with the Gigapack III gold packaging extract (Stratagene, Amsterdam), according to the supplier's instructions.

The libraries were screened using the P18a oligonucleotide (Table 3) as probe. P18a is derived from the catalytic site of pod4 (accession number AF155124), which is highly conserved among guaiacol peroxidases. P18a was labeled with $\gamma^{\prime \prime}$ P32 dATP, using the 5' end labeling kit (Amersham, Bucks, UK), and was purified on mini Quick Spin Oligo columns (Boehringer Mannheim, Indianapolis, IN, U.S.A.). The plaques were transferred to nylon Hybond N+ filters (Amersham Pharmacia, Vorsay, France). The membranes were prehybridized 3 $\mathrm{h}$ at $65^{\circ} \mathrm{C}$ in a buffer containing $6 \times \mathrm{NET}(0.9 \mathrm{M} \mathrm{NaCl}, 0.09 \mathrm{M}$ Tris, pH 8.3, 6 mM EDTA), 0.05\% SDS, 0.05\% NaPyrophosphate, $5 \times$ Denhardt's reagent, and $100 \mu \mathrm{g}$ of sheared salmon sperm DNA per $\mathrm{ml}$ and were hybridized overnight at $42^{\circ} \mathrm{C}$ in fresh buffer without DNA. The membranes were then washed $5 \mathrm{~min}$ at $42^{\circ} \mathrm{C}$ in $6 \times \mathrm{SSC}(1 \times \mathrm{SSC}$ is $0.15 \mathrm{M} \mathrm{NaCl}$ plus 0.015 $\mathrm{M}$ sodium citrate) and $0.1 \% \mathrm{SDS}, 30 \mathrm{~min}$ at $32^{\circ} \mathrm{C}$, and $5 \mathrm{~min}$ at $42^{\circ} \mathrm{C}$, before exposure to autoradiogram films.

Plaques that hybridized to P18a were purified by three rounds of replating and screening. Plasmids were excised from the phage according to the manufacturer's instructions (Clontech).

The $5^{\prime}$ and $3^{\prime}$ ends of a peroxidase-related expressed sequence tag (EST) provided by M. Patil and M. Essenberg (Oklahoma State University, Tulsa, U.S.A.) were cloned by PCR from the cDNA libraries, using the $5^{\prime}$ pod10 and $3^{\prime}$ pod10 primers (Table 3). An actin EST was also isolated from the cDNA libraries by PCR, using the degenerated primers ACT3 and ACT4, provided by J. Tregor (IRD, Montpellier, France) (Table 3). A 300-bp band was gel-purified and cloned into pGEM-T (Promega, Charbonnières, France). The POD cDNA sequences are available in the GenBank database.

The deduced proteins were aligned using the ClustalW (1.81) multiple sequence alignment program (Infobiogen, Paris).

\section{RT-PCR.}

Total RNA was extracted from water-treated and X. campestris pv. malvacearum-infected cotyledons by the guanidium thiocyanate/ $\mathrm{CsCl}$ method described by Maliyakal (1992), at different times after infiltration. Using specific primer pairs (Table 1), the expression profile of each cDNA clone was determined by RT-PCR. Total RNA $(7.5 \mu \mathrm{g})$ was reversetranscribed with StrataScript Reverse Transcriptase (Stratagene) using oligo- $(\mathrm{dT})_{18}$ as primer. PCR products were run on $1.5 \%$ agarose gels in Tris-acetate-EDTA buffer, and band intensities within each experiment were compared after ethidium bromide staining. For each primer pair, bands from three independent PCR reactions were cloned and were sequenced to confirm their identities. The entire experiment was repeated twice.

\section{ACKNOWLEDGMENTS}

We thank J. Leach (Kansas State University) for helpful discussion on defense peroxidase, P. Simon and C. Penel (University of Geneva, Switzerland) for useful discussion about the cDNA library screenings, and M. Essenberg (Oklahoma State University) for providing us with pod 10 EST.

\section{LITERATURE CITED}

Abraham, K. J., Pierce, M. L., and Essenberg, M. 1999. The phytoalexins desoxyhemigossypol and hemigossypol are elicited by Xanthomonas in Gossypium cotyledons. Phytochemistry 52:829-836. 
Al-Mousawi, A. H., Richardson, P. E., Essenberg, M., and Johnson, W. M. 1982. Ultrastructural studies of a compatible interaction between Xanthomonas campestris pv. malvacearum and cotton. Phytopathology 72:1222-1230.

Assigbetsé, K., Cuny, G., Valette, V., Delannoy, E., Bresson, E., Jalloul, A., Daniel, J. F., Geiger, J. P. and Nicole, M. 1999. Cloning and characterization of a bacterial-induced peroxidase encoding cDNA from cotton (GenBank accession No. AF155124). Plant Physiol. 121:312.

Bestwick, C. S., Brown, I. R., and Mansfield, J. W. 1998. Localized changes in peroxidase activity accompany hydrogen peroxide generation during the development of a non-host hypersensitive reaction in Lactuca sativa L. Plant Physiol. 118:1067-1078.

Blee, K. A., Jupe, S. C., Richard, G., Zimmerlin, A., Davies, D. R., and Bolwell, G. P. 2001. Molecular identification and expression of the peroxidase responsible for the oxidative burst in French bean (Phaseolus vulgaris L.) and related members of the gene family. Plant Mol. Biol. 47:607-620.

Bolwell, G. P. 1999. Role of active oxygen species and NO in plant defense responses. Curr. Opin. Plant Biol. 2:287-294.

Bolwell, G. P., Bindschedler, L. V., Blee, K. A., Butt, V. S., Davies, D. R. and Gardner, S. L., Gerrish, C., Minibayeva, F. 2002. The apoplastic oxidative burst in response to biotic stress in plants: A three-component system. J. Exp. Bot. 53:1367-1376.

Bradford, M. M. 1976. A rapid and sensitive method for quantitation of microgram quantities of protein utilizing the principle of protein-dye binding. Anal. Biochem. 72:248-254.

Brown, I., Trethowan, J., Kerry, M., Mansfield, J., and Bolwell, G. P 1998. Localization of components of the oxidative cross-linking of glycoproteins and of callose synthesis in papillae formed during the interaction between non-pathogenic strains of Xanthomonas campestris and french bean mesophyll cells. Plant J. 15:333-343.

Carpin, S., Crevecoeur, M., de Meyer, M., Simon, P., Greppin, H., Penel, C. 2001. Identification of a $\mathrm{Ca}^{(2+)}$-pectate binding site on an apoplastic peroxidase. Plant Cell 3:511-20.

Cason, E. T., Jr., Richardson, P. E., Essenberg, M. K., Brinkerhoff, L. A., Johnson, W. M., and Venere, R. J. 1978. Ultrastructural cell wall alterations in immune cotton leaves inoculated with Xanthomonas malvacearum. Phytopathology 68:1015-121.

Chittoor, J. M., Leach, J. E., and White, E. F. 1997. Differential induction of a peroxidase gene family during infection of rice by Xanthomonas oryzae pv. oryzae. Mol. Plant-Microbe Interact. 10:861-871.

Chittoor, J. M., Leach, J. E., and White, E. F. 1999. Induction of peroxidase during defense against pathogens. Pages 171-193 in Molecular Biology Intelligence Unit: Pathogenesis-Related Proteins in Plants. S. K. Datta and S. K. Muthukrishnan, eds. CRC Press, New York.

Daï, G. H., Nicole, M., Martinez, C., Bresson, E., Daniel, J. F., Andary, C., and Geiger, J. P. 1996. Flavonoids accumulate in cell walls, middle lamellae and callose-rich papillae during an incompatible interaction between Xanthomonas campestris pv. malvacearum (Race 18) and cotton. Physiol. Mol. Plant Pathol. 49:285-306.

Davila-Huerta, G., Hamada, H., Davis, G. D., Stipanovic, R. D., Adams, C., and Essenberg, M. 1994. Cadinane-type sesquiterpenes induced in Gossypium cotyledons by bacterial inoculation. Phytochemistry 39:531-536

De Feyter, R., Yang, Y., and Gabriel, D. W. 1993. Gene-for-gene interactions between cotton $\mathrm{R}$ genes and Xanthomonas campestris pv. malvacearum. Mol. Plant-Microbe Interact. 6:225-237.

Do, H. M., Hong, J. K., Jung, H. W., Kim, S. H., Ham, J. H., and Hwang, B. K. 2003. Expression of peroxidase-like genes, $\mathrm{H}_{2} \mathrm{O}_{2}$ production, and peroxidase activity during the hypersensitive responses to Xanthomonas campestris pv. vesicatoria in Capsicum annuum. Mol. PlantMicrobe Interact. 16:196-205.

Essenberg, M., Grover, P. B., Jr., and Cover, E. C. 1990. Accumulation of antibacterial sesquiterpenoids in bacterially inoculated Gossypium leaves and cotyledons. Phytochemistry 29:3107-3113.

Follin, J. C., Girardot, B., Mangano, V., and Benitez, R. 1988. Nouveaux résultats sur le déterminisme génétique de la résistance foliaire totale du cotonnier (Gossypium hirsutum L.) à la bactériose (Xanthomonas campestris pv. malvacearum (Smith)) Dye, race 18 et 20. Cot. Fib. Trop. 3:167-175

Gabriel, D., Burges, A., and Lazo, G. R. 1986. Gene for gene interaction of five cloned avirulence genes from Xanthomonas campestris pv. malvacearum. Proc. Natl. Acad. Sci. U.S.A. 83:6415-6419.

Gadea, J., Mayda, M. E., Conejero, V., and Vera, P. 1996. Characteriza- tion of defense-related genes ectopically expressed in viroid-infected tomato plants. Mol. Plant-Microbe Interact. 9:409-415.

Hilaire, E., Young, S. A., Willard, L. H., McGee, J. D., Sweat, T., Chittoor, J. M., Guikema, J. A., and Leach, J. E. 2001. Vascular defense responses in rice: Peroxidase accumulation in xylem parenchyma cells and xylem wall thickening. Mol. Plant Microbe Interact. 14:1411-9.

Hillocks, R. J. 1992. Cotton Diseases. CAB International. Redwood Press. Melksham, U.K.

Hiraga, S., Sasaki, K., Ito, H., Ohashi, Y., and Matsui, H. 2001. A large family of class III plant peroxidases. Plant Cell Physiol. 42:462-468

Hopper, D. G., Venere, R. J., Brinkerhoff, L. A., and Gholson, R. K. 1975. Necrosis induction in cotton. Phytopathology 65:206-213.

Innes, N. 1983. Bacterial blight of cotton. Biol. Rev. 58:157-176.

Jalloul, A., Montillet, J. L., Assigbetsé, K., Agnel, J. P., Delannoy, E., Daniel, J. F., Marmey, P., Geiger, J. P., and Nicole, M. 2002. Lipid peroxidation in cotton-Xanthomonas interactions. Role of lipoxygenases during the hypersensitive reaction and leaf blight. Plant J. 32:1-12.

Maliyakal, E. J. 1992. An efficient method for isolation of RNA and DNA from plants containing polyphenolics. Nucleic Acids Res. 20:2381

Martinez, C., Geiger, J. P., Bresson, E., Daniel, J. F., Dai, G. H. Andary, C., and Nicole, M. 1996. Isoperoxidase are associated with resistance of cotton to Xanthomonas campestris pv. malvacearum (race 18). Pages 327-332 in: Plant Peroxidase: Biochemistry and Physiology O. Obinger, U. Burner, R. Ebermann, C. Penel, and H. Greppin, eds. University of Geneva, Switzerland and University of Vienna, Austria

Martinez, C., Montillet, J. L., Bresson, E., Agnel, J. P., Daniel, J. F. Geiger, J. P., and Nicole, M. 1998. Apoplastic peroxidase generates superoxide anions in cells of cotton cotyledons undergoing the hypersensitive reaction to Xanthomonas campestris pv. malvacearum race 18. Mol. Plant-Microbe Interact. 11:1038-1047.

Martinez, M., Baccou, J. C., Bresson, E., Baissac, Y., Daniel, J., Jalloul, A., Montillet, J. L., Geiger, J.P., Assigbetse, K., and Nicole, M. 2000. Salicylic acid mediated by the oxidative burst is a key molecule in the local and systemic resistance of cotton challenged by an avirulent race of Xanthomonas campestris pv. malvacearum race 18. Plant Physiol. 122:757-766.

Nicholson, R., and Hammerschmidt, R. 1992. Phenolic compounds and their roles in disease resistance. Ann. Rev. Phytopathol. 30:369-389.

Patzlaff, M., and Barz, W. 1978. Peroxidatic degradation of flavanones. Zeit Naturfor. 33c:675-684.

Penel, C., and Greppin, H. 1996. Pectin binding proteins: Characterization of the binding and comparison with heparin. Plant Physiol. Biochem. 34:479-488.

Penel, C., Van Cutsem, P., and Greppin, H. 1999. Interactions of a plant peroxidase with oligogalacturonides in the presence of calcium ions. Phytochemistry 51:193-198.

Penel, C., Carpin, S., Crèvecoeur, M., Simon, P., and Greppin, H. 2000. Binding of peroxidase to $\mathrm{Ca}^{2+}$ pectate: Possible significance for peroxidase function in cell wall. Plant Peroxidase Newsl. 14:33-40.

Tognolli, M., Penel, C., Greppin, H., and Simon, P. 2002. Analysis and expression of the class III peroxidase large gene family in Arabidopsis thaliana. Gene 288:129-38.

Reimers, P. J., Guo, A., and Leach, J. E. 1992. Increased activity of a cationic peroxidase associated with an incompatible interaction between Xanthomonas oryzae pv. oryzae and rice (Oryza sativa). Plant Physiol. 99:1044-1050

Venere, R. J. 1980. Role of peroxidase in cotton resistant to bacterial blight. Plant Sci. Let. 20:47-54.

Welinder, K. G. 1992. Superfamily of plant, fungal and bacterial peroxidases. Curr. Opin. Struct. Biol. 2:388-393

Welinder, K. G., Justesen, A. F., Kjaergard, I. V. H., Jensen, R. B. Rasmussen, S. K., Jespersen, H. M., and Duroux, L. 2002. Structural diversity and transcription of class III peroxidases from Arabidopsis thaliana. Eur. J. Biochem. 269:6063-6081.

Wojtasjeck, P. 1997. Oxidative burst, an early plant response to pathogen infection. Biochem. J. 322:681-692.

Yamasaki, H., Sakihama, Y., and Ikehara, N. 1997. Flavonoid-peroxidase reaction as a detoxification mechanism of plant cells against $\mathrm{H}_{2} \mathrm{O}_{2}$. Plant Physiol. 115:1405-1412.

Young, S. A., Guo, A., Guikema, J. A., White, F. F., and Leach, J. E. 1995. Rice cationic peroxidase accumulates in xylem vessels during incompatible interaction with Xanthomonas oryzae pv. oryzae. Plant Physiol. 107:1333-1341. 